\title{
Heat Shock Protein
}

National Cancer Institute

\section{Source}

National Cancer Institute. Heat Shock Protein. NCI Thesaurus. Code C16672.

A family of highly-conserved proteins that are synthesized in response to hyperthermia (heat shock), hypoxia, or other stresses that appear to increase cellular thermal tolerance and enable cells to recover from stress. Some heat shock proteins may protect other proteins from denaturation, degradation or perform functions essential to cell survival under these conditions. 